\title{
Sources of Civil Law: The Wainwright Collection
}

by

M. L. Renshawe and J. E. C. Brierley

The "Wainwright Collection" of books relating to the history and sources of French private law is housed in McGill University's Law Area Library. The collection is an unique, valuable and useful resource for Civil Law jurists, scholars and historians. This essay examines briefly the scope and importance of the collection and relates how the core collection was acquired from Olivier-Martin for the McGill Faculty of Law through the generosity of the late Mr. Arnold Wainwright, Q. C.

La "Collection Wainwright" d'ouvrages se rapportant à l'histoire et aux sources du droit privé français se trouve à la bibliothèque de droit de l'universite McGill. Cette collection est un instrument unique et inestimable pour les juristes, érudits et historiens du droit civil. L'auteur de cet article analyse brièvement la portée et l'importance de cette collection et relate comment la faculté de droit de McGill s'est portée acquéreur de la collection principale auprès d'Olivier-Martin grâce à la générosité de feu Arnold Wainwright, C. R.

Bound in worn, cracked, rubbed and dirty leather, the book measures approximately $22.5 \mathrm{~cm}$ wide by $28 \mathrm{~cm}$ in height. It would be described by bibliographers and booksellers as a quarto.

The spine is peeling and the hinges are split from use and dryness. The gilt stamped lettering and designs on the spine have faded almost to obliteration and the title can only be read with difficulty.

The inside covers are lined with fading and worn marbled paper in red, blue and green abstractions.

The volume contains 726 pages that, while stained slightly in places, are generally as clean and supple as those of a book published yesterday. None of the brittleness or decomposition associated with the cheaper, acidic paper of the mid-nineteenth century is to be found here despite the devastation of the binding.

The title page, in red and black print, gives the title in full:

"L'ART

DE VERIFIER LES DATES

DES FAITS HISTORIQUES, DES CHARTES, DES CHRONIQUES,

ET AUTRES 


\section{ANCIENS MONUMENS}

Depuis la Naiffance de Notre-Seigneur;

PAR LE MOYEN

\section{D'UNE TABLE CHRONOLOGIQUE,}

où l'on trouve les années de JESUS-CHRIST, \& de l'Ere

d'Efpagne, les Indictions, le Cycle Pafcal, Les Pâques

de chaque année, les Cycles Solaires \& Lunaires, etc."

The title page also indicates that the volume contains "UN CALENDRIER PERPETUEL, L'HISTOIRE ABREGÉE DES CONCILES, DES PAPES, DES EMPEREURS ROMAINS..." and so on.

Finally, the title page notes that the volume was the work of "des Religieux Benedictins de la Congrégation de S. Maur" and published in Paris by Desprez and Cavelier, "avec approbation et privilege du roi."

The date of the publication is "M. D C C. L."

The book is an 18 th century reference book. It has obviously been well used at some point but is otherwise unremarkable either in its content or binding. However, the book is a survivor. It has escaped the ravages of time and man, the terrors of the French Revolution, the destruction of two world wars, and safely made its modern odyssey by sea from Paris to Montreal where it rests on the library shelves of the Wainwright Collection housed in McGill's Law Area Library. Indeed, on the inside of the front cover is a bookplate that reads:

\section{"Ancienne Collection}

\section{OLIVIER-MARTIN}

presented by

\section{ARNOLD WAINWRIGHT, Q. C."}

Another bookplate indicates that the work is the property of the McGill University Law Library.

The book was acquired by French scholar François Olivier-Martin in 1902, as indicated by his signature and notation found on one of the inside pages. 1902 was also the year Arnold Wainwright graduated from the McGill Faculty of Law.

While the book is unremarkable, except perhaps for its durability, the story of how the book arrived at McGill and became a part of the Wainwright Collection is unusual and interesting. 
This short essay is the story of this book and many others that eventually became the "Wainwright Collection" of the Faculty of Law. The main characters of the story are the French professor of Law, François Olivier-Martin and Montreal lawyer Arnold Wainwright, exact contemporaries but unknown to each other. Others who played important roles include Marianne Scott, then Law Librarian of the Faculty of Law and now National Librarian of Canada, and J. G. Castel, then Professor of Law at McGill and now Professor of Law at Osgoode Hall Law School, York University.

\section{The Wainwright Gift}

On Saturday, February 8, 1958, a small ceremony was held in the Faculty of Law, 3644 Peel Street, to mark the formal presentation of the Olivier-Martin collection to the Faculty by Mr. Wainwright. Present were the Honorable W. B. Scott, Chief Justice of the Quebec Superior Court; French Ambassador to Canada, His Excellency Francis Lacoste; Bâtonnier General of the Quebec Bar Hugh O'Donnell and W. C. J. Meredith, Dean of McGill Faculty of Law. Also present was Arnold Wainwright, Q. C., who had purchased the private library of the late Professor Olivier-Martin of the University of Paris (Figure 10).

The Olivier-Martin collection of approximately 1200 volumes dealing primarily with the history and sources of French private law was considered at that time to be one of the most comprehensive private law libraries in France. Dean Meredith told those assembled at the ceremony that the collection "will enable Quebec lawyers, students, historians and others to probe the sources from which our civil law springs." 1 Dean Meredith also noted that the late Professor Olivier-Martin had expressed his desire that a Quebec university acquire his collection.

Mr. Wainwright was quoted as saying that "he was fascinated by our [Quebec] civil law" and that it was his hope that the collection would encourage graduate and undergraduate research into the Quebec Civil Code. ${ }^{2}$

Ambassador Lacoste, in his brief address, said that he was proud that the collection had found a place in "this famous and venerable university" to which he, himself, had come years ago as a visiting student. ${ }^{3}$

\section{Arnold Wainwright}

Arnold Wainwright Q. C. (1879-1967), a member of the Quebec Bar and prominent Montreal practitioner, was a graduate of McGill and a long-time associate and friend of the Faculty of Law. He received his B.A. in 1899 and his B.C.L. in 1902. After graduating, the Faculty awarded him the Macdonald Travelling Scholarship which enabled him to continue his studies in Paris.

In 1909 he joined the teaching staff of McGill as a part-time lecturer in Civil Law which he taught at McGill for the next twenty-five years. He was named professor emeritus in 1934 and was awarded an honorary degree of Doctor of Civil Law by McGill in 1963. 


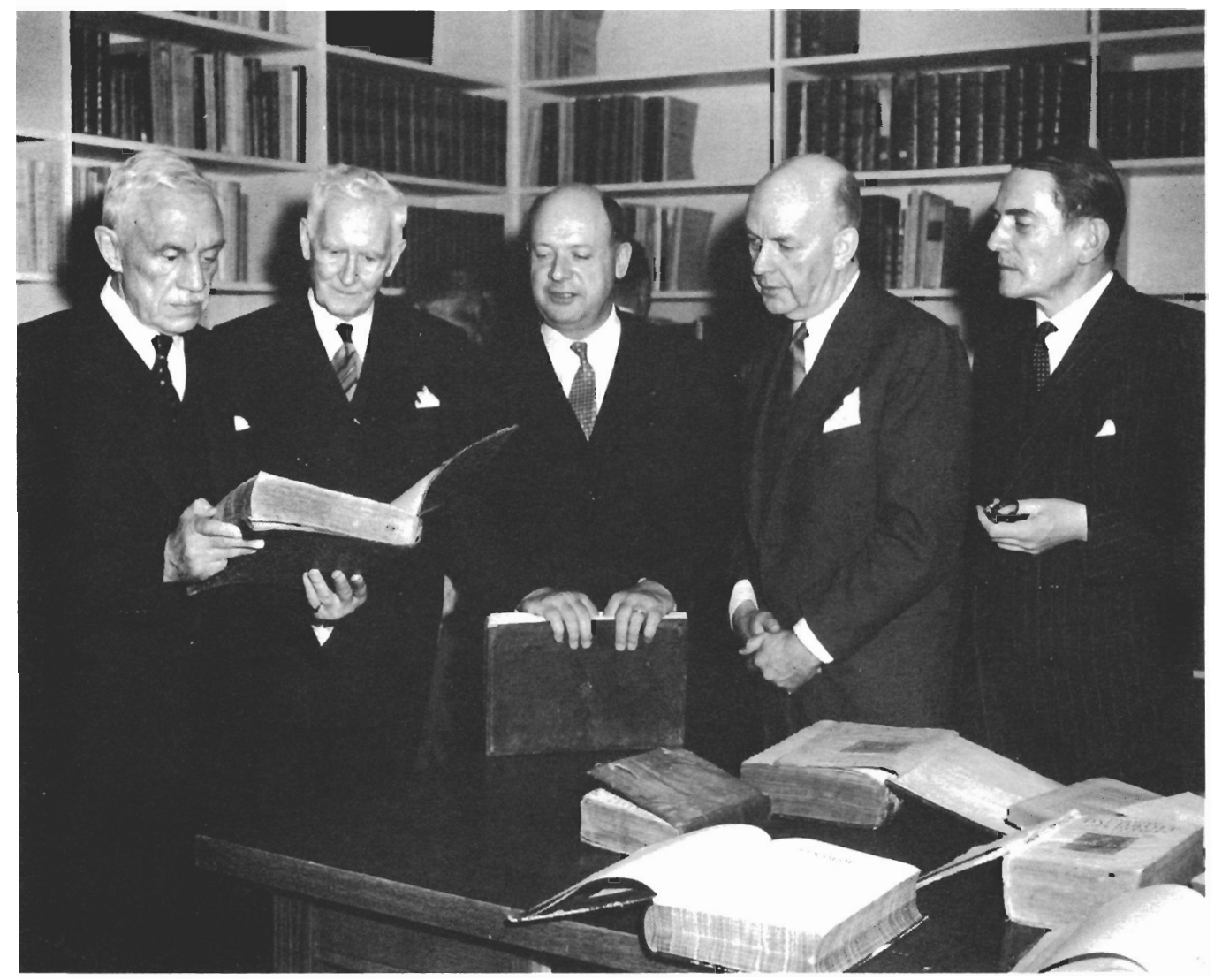

Fig. 10. Presentation of the Olivier Martin Collection, February 8, 1958. (L to R): W. B. Scott, Arnold Wainwright, Francis Lacoste, Hugh O'Donnell and W. C. J. Meredith. (Courtesy of the Gazette. Montreal) 
As the time of his retirement from the practice of law, he was the senior partner in the firm of Wainwright, Elder, Laidley, Leslie, Bourgeois and Doheny in Montreal. After retirement he continued to act as senior counsel for the firm and as director of several companies including FryCadbury Ltd.

In addition to his teaching and practice of the Civil Law, Arnold Wainwright was a gifted pianist and collector of fine art. He donated his art collection, including many Krieghoff oils depicting 19th century life in Quebec, to the University. This collection is now housed in the McCord Museum.

Upon his death in 1967, Arnold Wainwright bequeathed the residue of his estate to McGill University for the benefit of the Faculty of Law. The legacy has enabled the Faculty to set up the Wainwright Trust which ever since has funded a generous scholarship programme, the Wainwright Lecture Series, the Wainwright Student Essay Prize, the invitation residence of Junior and Senior Wainwright Fellows. It has also provided for continuing financial support to the Law Library in the field of modern French private law and the history of French Law.

\section{François Olivier-Martin}

François Olivier-Martin (1879-1952) was a prominent historian of French Law in the tradition of the late 19th century French historians such as $C$. Lefebvre (1847-1922), P. F. Girard (1852-1926), Émile Chénon (1857-1927) and J. Brissaud (1854-1904). He taught at the University of Paris from 1921 to 1951 where he had the reputation of being a gifted professor.

He was a prolific writer. His three major publications were Histoire de la coutume de la prévôté et vicomté de Paris, 2 vols. in 3 (1922, 1926, 1930), a magisterial study of the preponderant body of French customary law; Organisation corporative de la France d'Ancien Régime (1938), and Histoire du droit français des origines à la Révolution (1948). He was a founder, with others, of "La Société Jean Bodin pour L'histoire comparative des institutions."4 He was also a collector of books on French legal history, customary law, church law and history, political science and other matters of personal scholarly interest, and it was his personal collection, including L'Art de Vérifier les Dates..., acquired over many years and from various sources, that became the core of the Wainwright Collection.

The original Olivier-Martin library contained approximately 1200 volumes or 850 titles. Prof. J. G. Castel formerly of the Faculty of Law had travelled to Paris, negotiated the purchase from Madame Olivier-Martin and arranged for the books to be packed in six crates, sent from Paris to Le Havre, and then shipped to Montreal on board the "S. S. Montreal."

After the books arrived in Montreal and were delivered to the Faculty of Law, Marianne Scott, the Law Librarian, took charge. Under her supervision the books were sorted and shelved alphabetically by author in a special, third floor room of Old Chancellor Day Hall, apart from the main law library which was, at that time, also located in Old Chancellor Day Hall. 
New shelving had been especially installed for the collection and a special plaque made to identify the room as the "Wainwright Room."5 Books of a similar nature, already held by the main law library were then added th the Olivier-Martin library to form the "Wainwright Collection".

In 1960, Dénis de Boronkay, Assistant Librarian and cataloguer in the law library, trained in Hungarian law and a graduate of McGill's Library School, completed a two part bibliographical study of the Olivier-Martin collection. ${ }^{6}$ This study was prepared in several typescript copies but never formally published. Bound in red buckram, it still serves as a useful and interesting entrée to the original Olivier-Martin library.

Part I (Volume 1) of the study provides a detailed bibliographical description of each item with "authentic sentences" of the authors or editors selectively used to show the scope of each work.

Part II (Volume 2) contains seven indexes: 1. Index of Authors; II. Index of Titles; III. Index of Series in which many items are published; IV. Index of Theses; V. Index of Place Names, VI. Subject Index (in English); VII. Analytical Index (in French). The study did not include the folio volumes that were a part of the Olivier-Martin library.

In addition to his bibliographic analysis, Boronkay catalogued the Olivier-Martin titles so that scholars would have easy access to the collection using the Law Library card catalogue.

\section{Scope Of The Olivier-Martin Library}

In the tradition of the now classic historians who wrote in the late 19 th and early 20th centuries, there are five commonly accepted (although only approximative) chronological divisions of French law preceding the "modern" period which began in 1804:

1. Gallo-Roman, 50 B. C. -476 A. D.

2. Frankish Period, 6th - 10th centuries

3. Feudal Period (Middle Ages), 11 th -15 th centuries

4. Administrative Monarchy, 16th century - 1789

5. Revolutionary (or "Intermediate") Period, 1789-1804

The historical sources of law vary within each period and according to the geographical region of France and the field of law in question. Roman law, Canon law, customary law (droit coutumier), royal edicts and ordinances, judicial decisions of the French parlements and inferior courts and doctrinal comment are all elements that combine, in a variety of patterns, to constitute the legal "system." The documentary sources of French law therefore exhibit great complexity.

The Olivier-Martin library was especially rich in original materials from the fourth period (1500-1789) when a multitude of doctrinal commentators began the work of synthesizing these various elements of French private law. Their works paved the way for the Napoleonic codifications of the early 19th 
century that, in turn, laid the foundations of the modern French legal order.

The draftsmen of the great French Code civil of 1804 drew their inspiration particularly from the work of Robert-Joseph Pothier (1699-1772) and Jean Domat (1625-1695), as well as from the compiled works of the best known Roman jurists found in Justinian's Corpus Juris Civilis. The OlivierMartin library contained editions of the Oeuvres of both Pothier and Domat, as well as the important and preferred 1776 edition of Pothier's Coutumes...d'Orléans and an excellent late 19th century three volume edition in Latin and Greek of the Corpus Juris Civilis.

\section{The Wainwright Collection Today}

While the Olivier-Martin library of 1200 volumes was the core collection, the Wainwright Collection today consists of over 3000 volumes, (approximately 1700 titles), all of which are fully catalogued and classified. The generosity of Arnold Wainwright, continued through the Wainwright Trust, has enabled the Faculty of Law to purchase in the antiquarian book market many additional titles of interest to add to the original bequest of 1958. Some volumes have also been added to it over the years by other donors. The records for this collection appear at the present time only in the McGill Law Library card catalogue and not as yet in the McGill University Automated Catalogue (MUSE). Adding those records to MUSE will be a special project for the near future, as will adding temperature and humidity controls to the Wainwright Room of New Chancellor Day Hall to protect the collection from the fluctuations of environmental change.

Today the "Wainwright Room" is located on the fifth floor of New Chancellor Day Hall, built in 1968 adjoining Old Chancellor Day Hall. The collection is still shelved apart from the main law library collection and its use is restricted to scholars having legitimate research interests.

\section{Significance of the Collection To Canadian Legal Research}

The collection is of particular relevance to the historical development and contemporary operation of a large portion of Quebec law. Important parts of the legal system of metropolitan France were extended to the colony of New France in the 17th and 18th centuries, prior to its cession to the British Crown in 1763. Those elements relating to "private law" or droit civil, that is to say to "property and civil rights" of citizens as private individuals (as that term was understood at the time) were reaffirmed as the "law of Canada" by the enactment of the United Kingdom known as the "Quebec Act" of $1774 .^{7}$ Many of the distinctive institutions of contemporary Quebec private law therefore draw their origins from the "old French law" (ancien droit français) as expounded in the works forming a significant part of the Olivier-Martin collection.

When Quebec enacted its first Civil Code, in 1866, it was based upon these same sources, even though in form and style the Civil Code of Lower Canada was closely patterned upon the French Code civil of 1804. But the 
Quebec and French codes differ in their treatment of their largely similar historical sources. A leading difference between them is that in France, where the Napoleonic codes were envisaged as ushering in a new social order, the law as it had previously existed, i.e. prior to 1804 , was abrogated. In Quebec, on the other hand, the "old French law" as it had survived in Quebec down to 1866, was expressly maintained in those instances where the Civil Code did not contain any specific provision. The French "historical" sources of Quebec Civil Law thus remain a truly living source of contemporary law. ${ }^{8}$

The gift by Arnold Wainwright of the Olivier-Martin collection thus has a particular importance for Quebec lawyers over and above its general value for students of French legal history and civilization.

\section{$\underline{\text { Notes }}$}

1. Montreal Star, Tuesday, February 4, 1958.

2. Montreal Star, Monday, February 10, 1958, 8 .

3. Ibid.

4. For details of his life and career, see G. Lepointe. "François OlivierMartin." Revue historique de droit français et étranger. 30 (1953): 1-29.

5. McGill Law Library, Annual Report for 1957-58, submitted by Marianne Scott, Law Librarian and available in the McGill University Archives. We are indebted to Mrs. Phebe Chartrand of the McGill Archives for locating this report. See also Marianne Scott. "The Wainwright Collection." McGill Law Journal 8 (1961): 57-60.

6. Olivier-Martin's Collection of Books on French Legal History, History, Church History, Canon Law, Political Science, Public Finance: Analytical Bibliography. 2 vols. Montreal, 1960.

7. Stats. U. K., 14 Geo. III, c. 83.

8. The codification of Quebec Civil Law in 1866 in relation to its historical sources is analyzed in J. E. C. Brierley. "Quebec's Civil Law Codification: Viewed and Reviewed." McGill Law Journal 14 (1968) 514. 